\title{
Putino Rusija: režimo prigimtis ir prieštaravimai ${ }^{* *}$
}

Šiame straipsnyje apžvelgiama vieša informacija, kuri verčia abejoti tradicine Vladimiro Putino režimo kaip „valdžios vertikalès“ koncepcija, taip pat kvestionuojama prielaida, kad būtent Putinas ir sukūrẻ ši režimą, o jo kūrimo pradžią reikia sieti su Putino atėjimu ị Rusijos valdžią 2000 metais. Straipsnyje bandoma pagrịsti teiginị, kad procesai, pasibaigę tuo, ką dabar vadiname Putino režimu, prasidejjo dar prieš Sovietų Sąjungos žlugimą ir vyko Rusijoje visą vadinamąji Boriso Jelcino demokratijos laikotarpị. Jie susiję su net pačioje Sovietų Sajungoje visagale laikytos slaptosios tarnybos KGB planais reformuoti Sovietų Sąjungą, turto išdalijimu Sovietų Sąungai žlugus ir žmonèmis, kurie buvo arba specialiai rengti minètam SSRS reformavimui arba patys buvo KGB atstovai, o dabar būtent jie yra ịsitvirtinę Rusijos valdžioje. Šio straipsnio tikslas ir yra atskleisti šią Putino režimo prigimties pusę, kuri gerokai keičia visą ịprastą paveikslą.

\section{Ivadas}

Rusijos prezidentas Vladimiras Putinas pastaraisiais metais nesiliauja stebinti Vakarų ne tik vis agresyvesniais veiksmais ịvairiose pasaulio vietose, bet ir tuo, kad jo režimas esą imasi veiksmų, kurie, bent jau remiantis Vakarų logika ir mąstymu, gali jị sužlugdyti ${ }^{1}$.

Todèl nuolat kyla klausimas, koks yra galutinis Kremliaus tikslas. Ne mažiau svarbu atsakyti ir ị tai, ar tai yra tik paties Putino, kuris galbūt rūpinasi tik savo išlikimu ar net yra atitrūkęs nuo realybès, kaip suformulavo Vokietijos

\footnotetext{
" Marius Laurinavičius - Hudsono instituto Vašingtone analitikas. Adresas korespondencijai: 1201 Pennsylvania Avenue, N.W. Suite 400 Washington, DC 20004, USA, tel: + 1 202-974-2400, el.p.: mlaurinavicius@hudson.org.

${ }^{*}$ Straipsnis parengtas autoriui stažuojantis Europos politikos analizès centre - CEPA (Center for European Policy Analysis), Vašingtone. Šiame straipsnyje pateikti vertinimai ir mintys yra be išimčių tik autoriaus ir niekada negali būti vertinamos kaip CEPA, Hudsono instituto, arba bet kurios kitos analitinès institucijos, su kuria yra susijęs autorius, oficiali pozicija ar analizès rezultatas.

${ }^{1}$ Satler P., „Putin Meets Economic Collapse With Purges, Broken Promises“, Newsweek, 6/28/15, http:// www.newsweek.com/putin-meets-economic-collapse-purges-broken-promises-347565; Kozyrev A.V., Russia's Coming Regime Change, The New York Times, July 20, 2015, http://www.nytimes.com/2015/07/21/ opinion/russias-coming-regime-change.html?_r=0; Kaylan M., "Putin’s Syria Gambit Could Be His Waterloo", Forbes, 30/09/2015.
} 


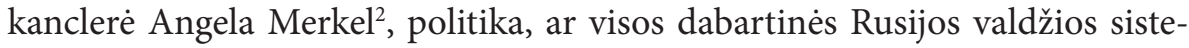
mos tikslai ir siekiai, kurie kažin ar pasikeistų net Putinui dèl kokių nors priežasčių pasitraukus iš posto.

Norint atsakyti i abu šiuos klausimus, Putino režimo prigimties tyrinèjimas tampa esminiu ir nepakeičiamu bet kurios prielaidos pagrindu. Nepaisant Putino režimo prigimties, sunku tikètis, jog įmanoma suprasti ir jo veiksmus ir šių veiksmų pagrịstumą.

Galima netgi teigti, kad klaidingas Putino režimo suvokimas gali būti viena pagrindinių priežasčiu, neleidžiančių ne tik geriau suprasti, ko siekia Kremlius imdamasis veiksmų, kurie, remiantis Vakarų logika, gali jị sužlugdyti, bet ir bent iš dalies prognozuoti tolesnes šio režimo keliamas grèsmes ir iššūkius Vakarams.

\section{Kas Putino režimo sistemoje yra pats Putinas?}

\subsection{Vakaruose vyrauja valdžios vertikalés koncepcija}

Naujasis caras: Vladimiro Putino iškilimas ir valdymas (The New Tsar: the Rise and Reign of Vladimir Putin) - šis garsaus The New York Times žurnalisto ir buvusio vieno ịtakingiausių JAV analitinių centrų Wilson Center bendradarbio Steveno Lee Myerso 2015 metų rudenị išleistos knygos pavadinimas geriausiai iliustruoja, kaip tiek Vakaruose, tiek Lietuvoje iki šiol ịsivaizduojama dabartiné Rusijos valdžios sistema, kurioje pats prezidentas Putinas laikomas ne vien jos simboliu, bet ir sistemos kūrèju, vienvaldžiu jos vadovu (arba tiesiog naujuoju „caru“), visų šios sistemos sèkmių ir nesèkmių kaltininku ir net išlikimo garantu.

„Asmenybès nulemia istoriją ne mažiau negu geografija. Ir nèra kitos asmenybès, kuri turètų tokią lemiamą ịtaką XXI amžiaus Europai, kaip Vladimiras Putinas. „Naujasis caras" yra jaudinantis, nepaprastai išsamus Putino apibūdinimas, kuris labai ịtikinamu, beveik šekspyrišku būdu paaiškina, kodèl jis elgiasi taip, kaip elgiasi“"3. Taip suformuluotos vienu iš JAV geopolitikos

\footnotetext{
${ }^{2}$ Paterson T. Ukraine crisis: Angry Angela Merkel questions whether Putin is 'in touch with reality', The Telegraph, 03 Mar 2014,

http://www.telegraph.co.uk/news/worldnews/europe/ukraine/10673235/Ukraine-crisis-Angry-AngelaMerkel-questions-whether-Putin-is-in-touch-with-reality.html.

${ }^{3}$ Kaplan D., „About The New Tsar", http://www.penguinrandomhouse.com/books/220562/the-new-tsarby-steven-lee-myers.
} 
guru laikomo Roberto D. Kaplano pagyros Myerso knygai patvirtina pasaulyje vyraujantị požiūrị ị Putino režimo prigimtį ir jo veikimo principus.

„Valdžios vertikalès" koncepcija Rusijos režimą iš esmès apibūdina kaip ištikimybès, lojalumo ir visiško pavaldumo vienam asmeniui sistemą. Joje esą viešpatauja šios sistemos kūrèjas prezidentas Putinas, o visos kitos valdžios grandys sudaro žemyn besidriekiančią piramidę, kurios užduotis tik vykdyti viršūnès (arba „caro“) nurodymus, iggvendinti jo idèjas. Kurdamas šią sistemą Putinas neva todèl ị valdžią atsivedè savo asmeninius draugus ir bendražygius, kurie dabar užtikrina tokios vertikalès funkcionavimą.

„Visi žino, ką jie turi daryti ir kada jie turi tai daryti. Jie taip pat supranta, kad yra atskaitingi asmeniui viršuje - tokia yra ideali Putino sistemos esmè. Tai yra esminis valdžios vertikalès, kurią Putinas, centralizuodamas valstybès aparatą, bandè sukurti pirmajame XXI amžiaus dešimtmetyje, elementas. Žmogus pačioje viršūneje nurodo misiją ir nustato tikslus. Bet kas kitas nuo viršaus iki pat apačios federaliniame valdžios aparate turi didesnès ar mažesnès atsakomybès ribas, siekdamas šių tikslų. Tas pats taikytina ir regioniniu lygiu“. Tokiais žodžiais valdžios vertikalès apibrěžimą savo knygoje Mr. Putin: Operative in the Kremlin dèsto žinomi Rusijos ekspertai Fiona Hill and Cliffordas G. Gaddis".

Tiesa, Vakarų analitikų darbuose galima rasti ir bandymų bent iš dalies abejoti tradicinès „valdžios vertikalès“ koncepcijos realumu, kai kalbama apie konkrečias režimo veikimo detales, arba bent jau kvestionuoti šios sistemos veikimo sèkmingumą. Tokias abejones, ypač nagrinèdamas vadinamajj Putino ir tuomečio prezidento Dmitrijaus Medvedevo tandemo fenomeną, dar 2011 metais suformulavo kitas žinomas Rusijos ekspertas, tuometis NATO gynybos koledžo, o dabar „Chatham House“ analitikas Andrew Monaghanas 5 .

Dar anksčiau, 2010 metais savo išleistoje knygoje dar vienas Vakaruose pripažintas Rusijos ekspertas Richardas Sakwa pateikia labai iškalbingą detalę. Esą politologas, ilgametis Valstybès Dūmos narys ir fondo „Ruskij mir“ vadovas Viačeslavas Nikonovas, kurị pagrịstai galima laikyti vienu Putino režimo „karių“, suskaičiavo, jog „daugiau negu 1800 Putino prezidento dekretų (ne instrukcijų ar paskyrimų, o politiką formuojančių sprendimų) nebuvo ịgyvendinti iki to laiko, kol jis paliko postą “" 2008 metais.

\footnotetext{
${ }^{4}$ Hill F., Gaddy C. G., Mr. Putin: Operative in the Kremlin, The Brookings Institution, 2013.

${ }^{5}$ Monaghan A. „The Russian Vertikal the Tandem, Power and the Elections“, June 2011, https://www. chathamhouse.org/sites/files/chathamhouse/19412_0511ppmonaghan.pdf .

${ }^{6}$ Sakwa R. The Crisis of Russian Democracy: The Dual State, Factionalism and the Medvedev Succession, Cambridge University Press, 2011.
} 
Tiek tokios detalès, tiek ir kiti faktai rodantys Putino režimo veikimą, atrodytų, turètų tapti pagrindu rimčiau suabejoti valdžios piramidès koncepcija ir Putino kaip „caro“ vaidmeniu. Juk žinant, kad „caro" nurodymai gali būti masiškai nevykdomi pirštųsi dvi alternatyvios prielaidos: arba Putinas vis dèlto nèra vienvaldis „caras“, arba jis mažų mažiausiai labai silpnas „caras“, o to nè vienas valdžios vertikalès modelio šalininkas neteigia.

Tačiau bent jau Vakaruose šios abejonès iki šiol nebuvo išplètotos iki rimtesnio iššǔkio nusistovejjusiai tradicinei Rusijos režimo sampratai.

\subsection{Rusijoje „putinocentristiniam“ požiūriui iššūkis mestas jau ne kartą}

Kita vertus, pačioje Rusijoje ịprastai koncepcijai, jog Putinas yra dabartinès Rusijos valdžios sistemos alfa ir omega, iššūkis pastaraisiais metais mestas jau ne kartą, nors anksčiau, tenka pripažinti, čia taip pat vyravo tas pats „putinocentristinis“ požiūris.

„Karų iniciatoriai ir dalyviai tapo kokybiškai mažiau priklausomi nuo ¿̇vairių numanomos „Putino elito konvencijos“, susiklosčiusios pirmojoje pirmojo XXI amžiaus dešimtmečio pusèje, nuostatų. Tarp jų - nuo principo „nenešk šiukšlių iš namų“. Putino elitas jau nebevertina savęs kaip visumos, kad tarpusavio konfliktų atvejais apsiribotų išskirtinai metodais ir priemonèmis, kurie nedestabilizuotų visos sistemos. Sistemos destabilizavimas nuo šiol nebèra laikomas per didele kaina biurokratiniame (korporatyviniame) kare (susiremime, mūšyje). Tai taip pat tipiškas „persitvarkymo" simptomas ${ }^{\text {“7 }}$. Šitaip rašè 2013 metų gruodị savo analitinejje apžvalgoje „FSB ${ }^{8}$ raportas: Rusiški karai: didžiausi biurokratiniai, korporatyviniai, informaciniai konfliktai Rusijoje 2013 metais“ žinomas, anksčiau pačiam Kremliui artimu laikytas Rusijos analitikas Stanislavas Belkovskis.

Nors reikia pripažinti, kad nemažai Belkovskio įžvalgų (ypač apie Rusijos laukiantį dar vieną „persitvarkymo“ laikotarpị) nepasitvirtino, paties režimo aprašymas jau tada sunkiai buvo suderinamas su ịprastu ,valdžios vertikalès“ îvaizdžiu.

\footnotetext{
${ }^{7}$ Белковский С., „Доклад ФСБ: «Русские войны: крупнейшие бюрократические, корпоративные, информационные конфликты в России в 2013 году», М.: 2013, http://slon.ru/russia/doklda belkovskogo-1035081.xhtml.

${ }^{8}$ Belkovskis šioje santrumpoje naudoja žodžių žaismą: FSB yra ir KGB ịpedinès Rusijos Federalinès saugumo tarnybos (rus. Federalnaja služba biezopasnosti) ir paties Belkovskio ịkurtos institucijos „Stanislavo Belkovskio fondas" (rus. Fond Stanislava Belkovskogo) santrumpa.
} 
„Rusijos valdžia toli gražu nèra griežta vertikali struktūra, kurią valdo vienas žmogus. „Valdžios vertikalë“ - ne daugiau negu propagandinis antspaudas. Rusijos valdžia - tai klanų ir grupių, kurios konkuruoja tarpusavyje dèl resursų, konglomeratas. Vladimiro Putino vaidmuo toje sistemoje nekinta - tai teisejo ir tarpininko vaidmuo. Tiesa, itakingo teisèjo žodis, bent jau konfliktinèse situacijose, kol kas lieka lemiamas. Nuo 2000-ųjų metų dẻl ịvairių veiksnių susiformavo politinių sprendimų prièmimo stilius, kuris vis labiau primena Sovietų Sąjungos komunistų partijos politinị biurą. Didelę įtaką perejimui prie šio modelio turejo valstybinių korporacijų ir politikoje ir ekonomikoje kūrimas. „Politbiuro 2.0“ specifika pirmiausia yra ta, kad jo nariai beveik niekada nesirenka ị bendrus posėdžius. Antra, jo narių formalus statusas ne visada atitinka realią ịtaką priimant sprendimus. Ir trečia - aplink „Politbiurą 2.0“ susikūrè keletas elitinių grupuočių, kurias sąlyginai galima skirstyti $\mathfrak{i}$ „jègos“, „politines“, „technines“ ir „verslininkų“. Šios grupuotès, viena vertus, yra „Politbiuro 2.0" valdymo atrama, bet, kita vertus, jos nuolat kovoja tarpusavyje dèl

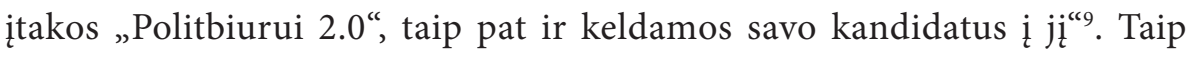
savo nuomonę apie tikrąją Rusijos valdžios struktūrą dar anksčiau - 2012 metais, po Putino sugrịžimo ị prezidento postą, apibūdino didelị tyrimą atlikęs ir daugiau negu 60 ịvairiausių ekspertų ir valdžiai artimų žmonių apklausęs žinomo Rusijos politikos konsultanto Jevgenijaus Minčenkos vadovaujamas centras „Minchenko consulting“.

Rusijos sociologè Olga Kryštanovskaja, ilgus metus tyrinėjanti Putino režimo elitą, teigia, kad net Dmitrijaus Medvedevo prezidentavimo laikotarpiu, kuris Vakaruose dažniausiai laikytas bandymu pasukti Rusiją kitokios politikos ir kitokio valdymo link, nè vienas iš maždaug 75 svarbiausių režimo asmenų, kuriuos jis vadina „kliučeviki“, neprarado savo posto ${ }^{10}$.

Tai reikštų, kad sistema liko visiškai stabili net tada, kai išoriškai atrodè, jog Rusija pajudejjo gerokai kitokiu keliu. Nagrinèjant visą Putino režimo sistemą (nes dabar jau turbūt būtų sunku ginčytis, kad Medvedevo valdymas - tik sudètinè to paties režimo dalis, o ne kažkoks esminis, bet nepavykęs bandymas ši režimą transformuoti), tai dar vienas labai svarbus faktas, kurị reikia prisiminti ieškant atsakymų ị iškeltus klausimus.

\footnotetext{
${ }^{9}$ Minchenko Consulting Communication Group, "Vladimir Putin’s Big Government and the "Politburo 2.0"', http://minchenko.ru/netcat_files/File/Big\%20Government\%20and\%20the\%20Politburo\%202_0.pdf ${ }^{10}$ Viktorov I., "The Legacy of Tandemocracy Russia’s political elite during Putin's third presidency: Interview with the sociologist Olga Kryshtanovskaya", Baltic Worlds, October 18, 2014, http://balticworlds. com/russia\%E2\%80\%99s-political-elite-during-putin\%E2\%80\%99s-third-presidency.
} 
Beje, pats žodis „kliučeviki“ pasirinktas kaip priešprieša ịsigalejjusiam „siloviki“, pabrèžiant, kad nepaisant visos įtakos, ne vien tik Putino valdžios vertikalei sukurti pasirinkti ir í valdžią neva paties Putino atvesti saugumo struktūrų atstovai kontroliuoja Rusiją. Sistema yra daug sudètingesnè, o paties Rusijos prezidento vaidmenị savo 2013 metų balandị (taigi Putinui jau antrą kartą sugrižus ị šalies vadovo postą) paskelbtame straipsnyje žinomas JAV ekspertas Donaldas N. Jensenas apibūdina ne „caro“, o veikiau „lèlių teatro tvarkdario“ (Puppet Master) sumaniomis manipuliacijomis (priešprieša „caro“ kietos rankos valdymui), užtikrinančio savo prezidentinę sprendimų priemimo autonomiją ịvaizdžiu ${ }^{11}$. Prisiminus, kad „,valdžios vertikalès“ sistemoje žmogus pačioje viršūneje (Putinas) nurodo misiją ir nustato tikslus. Bet kas kitas nuo viršaus iki pat apačios federaliniame valdžios aparate turi didesnès ar mažesnès atsakomybės ribas, siekiant šių tikslų, būtų sunku paaiškinti, kam „carui“ dar reikia sumanių manipuliacijų, kad užsitikrintų savo prezidentinę sprendimų prièmimo autonomiją.

\section{Ką apie režimo sistemą atskleidžia nuolatiniai elito tarpusavio karai?}

\subsection{Nuolatinis režimo bruožas, apie kurị diskutuota nuo pat Putino atėjimo ị valdžią}

Svarbu pastebèti, kad Putino Rusijos sistemos modelis kaip nuolatinė kova dèl išteklių ir įtakos tarp konkuruojančių valdžios grupuočių nèra jokia naujiena. Dabar jau dažniausiai pamirštama, tačiau, nors ir gerokai supaprastintai, dar pirmosios Putino kadencijos metu praejjusio dešimtmečio pradžioje visame pasaulyje dažniausiai diskutuota apie vadinamąją nuolatinę jau minètų „silovikų“ (jègos struktūrų atstovų) ir „liberalų“ priešpriešą Rusijoje ir jų kovos rezultatų nulemtus sprendimus ${ }^{12}$.

Toks nuolatinių elito karų dèl išteklių ir ịtakos (bet ne dèl Putino malonès ar ịtakos jam) modelis gerokai prieštarauja valdžios piramidès modeliui ar $\mathrm{Pu}$ tino, kaip „caro“, vaidmeniui. Ypač pripažistant, kad kova vyksta ir visuomet

\footnotetext{
${ }^{11}$ Jensen D. „Putin the Puppet Master“, Institute of Modern Russia, April 16, 2013, http://imrussia.org/en/politics/436-putin-the-puppet-master.

${ }^{12}$ Tsipko A., „Putin's choice: will the siloviki gain revenge on the liberals?", Prism, August 29, 2001, http:// www.jamestow n.org/single/?tx_ttnews\%5Btt_news\%5D=28025\&tx_ttnews\%5BbackPid\%5D=223\&no_ cache $=1 \#$. VjaO7tIrLs0.
} 
vyko ${ }^{13}$ ne vien dèl sprendimų Rusijos viduje, bet ir dèl šalies užsienio politikos. Pripažistama, kad Rusijos valstybès kursas net ir užsienio politikos srityje nèra nulemtas vienasmenių Putino sprendimų ${ }^{14}$, kuriais po karo Ukrainoje pradžios esą dabar jau nepatenkinta ar dèl jų net „apimta siaubo “15 didelè Rusijos elito dalis.

Nors galima teigti, kad koncepcija, jog Putino režimo esmę sudaro nuolatine , ,iberalų“ir „silovikų“ kova (arba dabar vadinama „karių“, „prekeivių“ ir „tikinčiųų “16 kova), yra gerokai supaprastintas realių procesų Rusijos atspindys, jis bent jau realiau parodo tai, kad sprendimai Rusijoje nepriklauso vien tik nuo Putino.

\subsection{Karų aukomis tampa ir Putino sajungininkai}

Dar vienas plačiai paplitęs "putinocentrizmo“ koncepcijos nulemtas mitas apie Putino Rusijos modeli yra tas, kad visa sistema esą yra paremta asmeniniais personifikuotų šios sistemos galios centrų ryšiais su pačiu Putinu.

Būtent todèl 2015 metų rugpjūtị nuskambèjusi žinia apie ilgamečio „Rusijos geležinkelių“ vadovo, buvusio Putino bendradarbio KGB struktūrose, garsiojo „Ozero" kooperatyvo nario ${ }^{17}$ Vladimiro Jakunino pasitraukimą iš posto buvo

\footnotetext{
${ }^{13}$ Staun J. „Siloviki versus Liberal-Technocrats: The Fight for Russia and its Foreign Policy“, Danish Institute for International Studies, http://www.isn.ethz.ch/Digital-Library/Publications/ Detail/?lang=en\&id=35135, „Russia: Liberals on the Offensive“, Stratfor, 2004. https://www.stratfor.com/ analysis/russia-liberals-offensive.

${ }^{14}$ Weir F. „Oligarchs out, 'siloviki' in? Why Russia's foreign policy is hardening“, The Christian Science Monitor, February 2, 2015,

http://www.csmonitor.com/World/Europe/2015/0202/Oligarchs-out-siloviki-in-Why-Russia-s-foreignpolicy-is-hardening.

${ }^{15}$ Meyer H., Reznik I., Arkhipov I., „Russian Billionaires in 'Horror' as Putin Risks Isolation“, Bloomberg Pursuits, July 21, 2014,

http://www.bloomberg.com/news/articles/2014-07-20/russian-billionaires-in-horror-as-putin-risksisolation.

${ }^{16}$ Stanovaya T. „A Battle Is Raging for Russian Foreign Policy“, The Moscow Times, Nov. 022015 http://www.themoscowtimes.com/opinion/article/a-battle-is-raging-for-russian-foreign-policy-oped/541516.html.

${ }^{17}$ Сетдикова Д., „Непотопляемый член кооператива “Озеро”, Радио Свобода, 17.06.2014, http://www. svoboda.org/content/article/25425252.html.
} 
sutikta vos ne kaip visą sistemą sukrečianti, o galbūt net pakeisti galinti žinia ${ }^{18}$. Nieko panašaus neįvyko ir atrodo, kad neįvyks. Putino režimas po Jakunino pasitraukimo nè kiek nepakito. Galima netgi teigti, kad Jakunino pasitraukimas, nepaisant to, kad šis žmogus ilgai laikytas artimiausio Putino rato atstovu, yra dar 2013 metais ị viešumą iškilusios klanų kovos tarp Jakunino ir „liberaliojo“ sparno Dmitrijaus Medvedevo vyriausybès narių logiška pasekmè ${ }^{19}$.

Be to, verta prisiminti, kad tai jau tikrai ne pirmas kartas, kai vadinamieji Putino draugai arba jo artimo rato atstovai tampa jau minètų režimo tarpusavio kovų aukomis.

Ryškiausias pavyzdys - kažkada „Putino bankininku“ ir taip pat vienu artimiausio prezidento rato žmonių vadintas Sergejus Pugačiovas. Šis dabar Didžiojoje Britanijoje ar Prancūzijoje nuo Kremliaus besislapstantis oligarchas netgi teigia, kad jis asmeniškai atvede Putiną i valdžią ${ }^{20}$. Kiek bendro tokie Pugačiovo teiginiai turi su realybe - atskiros diskusijos klausimas. Tačiau Pugačiovo likimas jau visiškai skiriasi, tarkim, nuo Boriso Berezovskio ar Vladimiro Gusinskio, kurie bėgti ị užsienị buvo priversti todèl, kad metė asmeninị iššūki pačiam Putinui ${ }^{21}$, arba Michailo Chodorkovskio, kuris ne tik metè toki pat asmeninị iššūkị Putinuii ${ }^{22}$, bet ir buvo pradèjęs kelti bent jau teorinę grèsmę visai valdžios sistemai Rusijoje, likimų.

Pugačiovas, kaip ir Jakuninas bei daugelis kitų klanų kovose kritusių anksčiau kone asmeniniais Putino draugais laikytų ịtakingų Rusijos veikèjų, ne tik nemetė jokio asmeninio iššūkio Rusijos prezidentui, bet ir nebandè pakeisti valdžios sistemos, kaip tai bandè padaryti Berezovskis, Gusinskis ir Cho-

\footnotetext{
${ }^{18}$ Bershidsky L., „Putin May Be Tiring of His Cronies“, BloombergView, Aug 18, 2015, http://www. bloombergview.com/articles/2015-08-18/putin-may-be-tiring-of-his-cronies, Reznik I., Arkhipov I. Tanas O., „Putin Said Ready to Revamp Inner Circle as Ally Yakunin Goes“, BloombergBusiness, August 18, 2015, http://www.bloomberg.com/news/articles/2015-08-18/putin-ally-yakunin-to-drop-railway-ceo-job-tobecome-a-senator, Kramer A. E., „Shake-Up in Moscow as Railways Chief, a Putin Friend, Is Reported Ousted“, The New York Times, Aug. 17, 2015 http://www.nytimes.com/2015/08/18/world/europe/head-ofrussias-national-railway-a-putin-associate-said-to-be-ousted.html?_r=0 , Korgunyuk Y., „The unraveling of crony capitalism in Russia?", Russia Direct, Aug 19, 2015, http://www.russia-direct.org/opinion/ unraveling-crony-capitalism-russia.

${ }^{19}$ Samoškaitè E., Ameliuškinas K. „Rusijoje vyksta keisti dalykai: kas slypi už dūmų uždangos“, Delfi, 2015 m. rugpjūčio 27 d., http://www.delfi.lt/news/daily/lithuania/rusijoje-vyksta-keisti-dalykai-kas-slypi-uzdumu-uzdangos.d?id=68835012.

${ }^{20}$ Belton C. "Sergei Pugachev: 'I personally brought Putin to power”, Financial Times, July 23, 2015, http://www.ft.com/intl/cms/s/0/5b24c19a-2ed7-11e5-8873-775ba7c2ea3d. html\#axzz3qwcnfJi5.

${ }^{21}$ Baker P., Glasser S., Kremlin Rising: Vladimir Putin's Russia and the End of Revolution, New York, 2005.

${ }^{22}$ Khodorkovsky, "Ten Years Ago Today: Khodorkovsky Dared To Challenge Putin On Corruption", February 19, 2013, http://www.khodorkovsky.com/ten-years-ago-today-khodorkovsky-dared-tochallenge-putin-on-corruption.
} 
dorkovskis. Ir vis dèlto niekuo nenusikaltę asmeniškai Putinui, šie buvę neva artimiausio Putinui rato atstovai, kažkodèl nesulaukẻ caru dažnai vadinamo lyderio pagalbos ar bent jau užtarimo, nors juos akivaizdžiai puolè bent jau tuo momentu tarsi mažiau Putinui artimi konkurentai, patekę ị Rusijoje ịprastas elito tarpusavio kovas.

Pavyzdžiui, Pugačiovo verslo imperiją išsidalijo daug kas, tačiau vienas akivaizdžiausių naudos gavèjų - Čečénijos lyderis Ramzanas Kadyrovas, tiksliau, už Kadyrovo verslą Maskvoje atsakingas Ruslanas Baisarovas ${ }^{23}$.

\section{3. [taka - ne vien tik valdžios postai}

Pugačiovo virsmo iš „Putino bankininko“ i ̣ režimo bẻgli istorija tik dar kartą patvirtina, kad Putino Rusija - tai nuolat tarpusavyje kovojančiu klanų, o ne „valdžios vertikalès“ sistema. Tačiau kova vyksta ne tik tarp „silovikų“ ir „liberalų“ arba tarp „silovikų ir "oligarchų“.

Dar 2007 metais apie nuolatinę pačių „silovikų“ klanų kovą savo milžinišką atgarsị turejusiame straipsnyje dienraštyje Komersant atvirai prabilo vieno tuomečių klanų lyderis, Federalinès narkotikų kontrolès tarnybos vadovas Viktoras Čerkesovas. Šis jo straipsnis buvo bene pirmas viešumoje pasklidęs „silovikų" klanų karų atgarsis.

Putinas tada gerokai apribojo abiejų kariavusių pusių galią, bet labiausiai nukentejo ir įtaką palaipsniui prarado pats Čerkesovas. 2008 metais netekęs Federalinès narkotikų kontrolès tarnybos vadovo posto jis dar paskirtas $\mathfrak{i}$ Federalinès ginklų tiekimo agentūros vadovo postą, tačiau 2010 metais pasitrauke ir iš jo.

Tolesnè jo karjera klostėsi ypač netikètai - 2011 metais Čerkesovas sèkmingai dalyvavo parlamento rinkimuose, bet ne kaip valdžios partijos „Vieningoji Rusija“, o kaip komunistų atstovas. Dabar jis yra Dūmos saugumo ir kovos su korupcija komiteto vicepirmininkas.

Čerkesovo pavyzdys Rusijos klanų sistemos modelį atskleidžia net keliais aspektais. Pirmiausia, dar kartą paneigia mitą, kad šioje sistemoje neliečiami gali jaustis asmeniniai Putino draugai ir bendražygiai. Nes būtent tokiu

\footnotetext{
${ }^{23}$ Смирнов С., Петрова С.,"Сергей Пугачев подал иск к России на $\$ 12$ млрд как гражданин Франции", Ведомости, 22.09.2015, http://www.vedomosti.ru/politics/articles/2015/09/22/609723-advokati-pugacheva-raskrili-detaliiska\#/politics/articles/2015/09/22/609723-advokati-pugacheva-raskrili-detali-iska\#!\%23\%2Fboxes\% 2F140737492434841, Шлейнов Р,, “Как устроен бизнес Руслана Байсарова“, Ведомости, 12.12.2011 http://www.vedomosti.ru/library/articles/2011/12/12/esli_budet_ploho_obraschus_i_k_kadyrovu.
} 
visada laikytas Čerkesovas, dirbęs su Putinu dar Leningrado KGB ir ilgus metus vadintas artimiausio Putino rato atstovu.

Be to, būtent klanų sistema atskleidžia tai, kad Čerkesovas, net ir praradęs buvusị asmeninį statusą, kurị garantavo aukštos pareigos, išlaiko pakankamą ịtaką. Nors šis politiku tapęs buvęs saugumietis nepretenduoja ị Minčenkos „Politbiuro“ sąrašą, jis mégaujasi galia, kuri, kaip teigia tas pats Minčenka, ne visada atitinka jo statusą priimant sprendimus.

Geriausias to pavyzdys - Čerkesovo žmona Natalija Čerkesova vis dar kontroliuoja Rusijos sąlygomis gana liberalias ir vis dar įtakingas žiniasklaidos priemones - agentūrą „Rosbalt" ir Sankt Peterburgo laikraštị „Peterburgskij Čas Pik“. Šios kontrolès išsaugojimas dar reikšmingesniu ženklu laikytinas dẻl to, kad vieną iš labiausiai cituojamų žiniasklaidos priemonių Rusijoje vadinamą agentūrą „Rosbalt“ net buvo bandyta uždaryti pagal Rusijoje ịprastą schemą. Agentūra buvo apkaltinta pažeidimais ir teismas prièmé sprendimą atšaukti jos licenciją. Tačiau 2014 metų pavasarị jau po agresijos Kryme, kai Rusijoje prasidèjo nauja spaudimo žiniasklaidai banga, Rusijos Aukščiausiasis teismas atšaukè žemesnių instancijų sprendimus ir grąžino licenciją gana liberalia žiniasklaidos priemone laikomai „Rosbalt ${ }^{\text {“24. }}$.

Todèl manyti, kad jau minètasis Jakuninas prarado ịtaką, tikrai gerokai per anksti. Veikiau galima teigti, kad Jakuninas ir jo klanas prarado galimybę savo pozicijas stiprinti per „Rusijos geležinkelius“ ir visus Rusijos mokesčiu mokètojus, o tokią galimybę gavo kitas klanas. Tačiau Jakunino ịtaką visiškai menkinti per anksti net ir žinant, jog jis atsisake tapti ir Federacijos Tarybos nariu, kaip buvo iš pradžiu pranešta.

\section{Ar gali „valdžios vertikalè“ egzistuoti be aiškių taisyklių?}

\subsection{Lojalumas Putinui nebūtinai garantuoja saugumą}

Viena svarbiausių taisyklių, kurią esą ịvedè Putinas, atėjęs ị valdžią, buvo laikytas tariamas nerašytas susitarimas, kad oligarchai ir ju sukauptas turtas bus saugūs, kol jie nesugalvos mesti iššūkio Putinui ir visai valdžios sistemai.

\footnotetext{
${ }^{24}$ Kasčiūnas L., Laurinavičius M., Keršanskas V., „Vladimir Putin’s pyramid of rule: Who really governs Russia?", DELFI by The Lithuanian Tribune, August 4, 2014, http://en.delfilt/central-eastern-europe/ vladimir-putins-pyramid-of-rule-who-really-governs-russia.d?id=65432116.
} 
Jau minèta, kad kalejjime arba „tremtyje“ užsienyje po Putino atejimo í valdžią atsidūrè tik tie oligarchai, kurie mete asmeninị iššūkị arba Putinui, arba visai sistemai (Chodorkovskis, Gusinskis ir Berezovskis).

Šiame kontekste gali atrodyti, kad tam tikrus ryškius režimo pokyčius iliustruoja vadinamoji oligarcho Vladimiro Jevtušenkovo byla, kurią spèta praminti „Jukos $2.0^{“ 25}$. Tačiau tokiam vertinimui akivaizdžiai prieštarauja jau minèta bankininko Pugačiovo istorija.

Panašiu pavydžių yra ir daugiau ${ }^{26}$. Tai dar vienas elito karų, o ne Putino valdžios piramidès ir netgi ne jo į valdžią atsivestų „silovikų“ susidorojimo su „oligarchu“ pavyzdys. O kalbant apie elito karus būtina pastebėti, kad net stipriausi Maskvoje įsitvirtinę klanai ne visuomet sugeba apsiginti net prieš regionų elito puolimą.

Jevtušenkovo bylą nuo pat pradžių vertinant ne tariamos Putino valdžios piramidès, o klanų kovos kontekste, buvo galima nesunkiai nuspèti, kad „Jukos byla 2.0“ čia nè nekvepia, bendrovès „Bašneft“ kontrolès siekia ne dar vienas Putino sąjungininkas ir artimo rato narys bendrovès „Rosneft“ vadovas Igoris Sečinas, o naujasis Baškirijos valdžios elitas. Bylos baigtis, kad „Bašneft“ atiteks valstybei (tiksliau Baškirijos valdžios kontrolei), o Jevtušenkovo neištiks Chodorkovskio likimas, taip pat buvo prognozuota ${ }^{27}$.

Tačiau tam buvo būtina patị Jevtušenkovą vertinti, kaip nuo pat pradžių savo verslo imperiją KGB klanų pagrindu kūrusį oligarchą, be to, ir dabar priskirtiną vienai galingiausių šalyje valdžios grupuočių, o ne tiesiog paviršutiniškai spręsti, kad ši byla reiškia kažkokị esminị lūžị tarsi būtų sulaužytas nerašytas susitarimas, kad tariamai vienvaldis Rusijos valdovas Putinas nelies stambiojo Rusijos verslo, kol šis bus lojalus valdžiai. Tokia taisyklè paprasčiausiai neegzistuoja. Nèra abejonių, kad nè vienam oligarchui nẻra leidžiama kèsintis ị pačią valdžios sistemą arba Putino autoritetą, tačiau lojalumas negali apsaugoti jų nuo tikimybės tapti tarpusavio karų aukomis.

\footnotetext{
${ }^{25}$ „Yukos 2.0?“', The Economist, Sep 18th 2014, http://www.economist.com/news/europe/21618848-arrestvladimir-yevtushenkov-recalls-mikhail-khodorkovsky-yukos-20.

${ }^{26}$ Laurinavičius M. "The case of Yevtushenkov: One more look at Russia through the prism of clan battles", DELFI by The Lithuanian Tribune, October 23, 201,4 http://en.delfi.lt/central-eastern-europe/the-case-ofyevtushenkov-one-more-look-at-russia-through-the-prism-of-clan-battles.d?id=66186694.

${ }^{27}$ Ten pat.
} 


\subsection{Boriso Nemcovo nužudymas Putino vienvaldystẻs kontekste}

Dar vienu visiško Putimo režimo taisyklių sulaužymo pavyzdžiu tenka laikyti vieno šalies opozicijos lyderių Boriso Nemcovo nužudymą 2015 metų vasario 27 dieną. Analizuojant ši nužudymą kitų Putino režimo nusikaltimų kontekste iš tiesų galima daug atskleisti apie patị režimą. Tačiau pagrindinè išvada yra ta, kad šiam režimui jau seniai nebėra ribų, kurių jis neperžengè anksčiau ${ }^{28}$, žudynès tapo šio režimo dalimi, o žmogaus gyvybè - absoliučiai bevertè.

„Valdžios vertikalès" kontekste viskas daug sudètingiau. Nesvarbu, ar vertinsime šią žmogžudystę, kaip tiesiogiai užsakytą Putino, kaip iki šiol teigia kai kurie Rusijos opozicijos atstovai, ar, atvirkščiai, kaip iššūki pačiam Putinui ${ }^{29}$, vertinant „valdžios vertikalès“ koncepcijos požiūriu, taisyklès šiuo atveju buvo akivaizdžiai sulaužytos.

Jeigu Nemcovo nužudymą užsakè Putinas, kyla klausimas, kodèl suimti i̇tariamieji yra ne šiaip atpirkimo ožiai, o vieno iš paties Putino patikètinių laikomo Čečénijos prezidento Ramzano Kadyrovo aplinkos žmonès. Ir kodèl Putinas kaip vienvaldis „caras“ nesustabdo nuo Nemcovo nužudymo kone atviru tapusio saugumo tarnybų atstovų karo su savo patiketiniu Kadyrovu ${ }^{30}$.

Jeigu vis dèlto nužudymas yra iššūkis pačiam Putinui, kaip tai dera su „valdžios vertikalès“ koncepcija ir Putino kaip „caro“ vaidmeniu. Ypač kai nè vienas iš įtakingų režimo veikẻjų nebuvo nei nubaustas, nei paprasčiausiai paaukotas ant Putino valdžios stiprinimo aukuro.

O juk iš karto po Nemcovo nužudymo šis nusikaltimas savo galimo poveikio Rusijos ateičiai prasme netgi klaidingai imtas lyginti su Sergejaus Kirovo nužudymu ${ }^{31}$, kuris laikomas vadinamojo Josifo Stalino didžiojo teroro preliudija. Šis klaidingas lyginimas, beje, taip pat, ko gero, yra nulemtas klaidingos prielaidos, kad Putino režimas yra valdžios vertikalè, kur Putinui tenka „caro“ (ar net Stalino) vaidmuo.

\footnotetext{
${ }^{28}$ Laurinavičius M. „Putin's Russia: What did Nemtsov's assassination reveal about the current regime?", DELFI by The Lithuanian Tribune, March 19, 2015, http://en.delfi.lt/central-eastern-europe/putins-russiawhat-did-nemtsovs-assassination-reveal-about-the-current-regime.d?id=67480244.

${ }^{29}$ Ten pat.

${ }^{30}$ Dubnov V. „Chechnya’s Strongman vs. Moscow's Men in Uniform: What Next?“, Carnegie Moscow center, http://carnegie.ru/commentary/?fa=59995.

${ }^{31}$ Dawisha K., „Nemtsov killing: A chilling historical parallel?“, CNN, February 28, 2015, http://www.cnn. com/2015/02/28/opinion/dawisha-nemtsov-killing, Sindelar D., „Nemtsov: Kremlin-Watchers Find Eerie Parallel In An 80-Year-Old Murder“, Radio Free Europe/Radio Liberty, March 01, 2015, http://www.rferl. org/content/russia-nemtsov-kirov-eerie-parallel/26876076.html.
} 


\section{Kokia vis dèlto yra Putino režimo prigimtis?}

\subsection{Esminè transformacija ar tik kitokia oligarchijos ir kleptokratijos forma?}

Nors dažniausiai teigiama, kad Putinas iš esmės pakeitė Rusijos valdžios sandarą, palyginti su Jelcino laikais, toks teiginys nèra visiškai tikslus. Dar 2007 metais Danielis Treismanas savo plačiai nuskambejusiame straipsnyje „Putin's Silovarchs“"32 atskleide, kad Jelcino laikais įsitvirtinusị oligarchinį valstybės valdymą iš esmès pakeitè tik kitokia jo forma - „silovarchija“.

„Silovarchijos“ - valstybės, kuriose saugumo tarnybų arba ginkluotuju pajègų veteranai dominuoja tiek politikoje, tiek versle - egzistavo ịvairiose šalyse, tarp jų Pietų Korèjoje ir Indonezijoje. Jos skiriasi nuo paprastų oligarchijų tuo, kad „silovarchai“ gali pasitelkti saugumo struktūras, valstybės prokurorus ir ginkluotąsias pajègas, kad ịbaugintų savo verslo partnerius ar net eksproprijuotų jų turtą“. Taip tada teigè Treismanas.

Tačiau kalbant apie Rusiją šis apibūdinimas teisingas tik iš dalies. Neabejotina, kad buvę ir esami saugumo struktūrų (ir kitų pareigūnų - armijos, milicijos, žvalgybos tarnybų) atstovai dominuoja tiek Rusijos politikoje, tiek versle.

Tačiau taip pat neabejojama, kad valstybės prokurorus, saugumo ir kitas jejgos struktūras tarpusavio kovoms net Jelcino valdymo laikais pasitelkdavo ir iki šiol pasitelkia tiek oligarchai, tiek su saugumo struktūromis esą nenusiję valdininkai (Treismanas iš tokių pirmiausia mini vieną įtakingiausių Jelcino valdymo atstovų Anatolijų Čiubaisą). Beje, svarbu paminèti, kad absoliuti dauguma tų oligarchų ir net nemaža dalis Jelcino valdymo laikotarpiu didelę ịtaką turejusių valdininkų daugiau ar mažiau išsaugojo savo pozicijas ir ịsigalejus „silovarchijai“, nors pagal teorinị modelị bent jau didžioji dalis turèjo užleisti pozicijas „silovarchams“, arba būti jų tiesiog valdomi.

\section{2. „Silovikai“ valdžioje atsidūrè jau Jelcino laikais}

Tačiau dar įdomesnis ir Putino režimo prigimčiai suprasti svarbesnis yra mitas apie tai, kad būtent Putinas atvedè ị valdžią „silovikus“. Ši mitą geriausiai paneigia jau minètos Kryštanovskajos sudaryta ir britų savaitraštyje The Econo-

\footnotetext{
${ }^{32}$ Treisman D. „Putin's Silovarchs“, 2007, http://www.sscnet.ucla.edu/polisci/faculty/treisman/Papers/ siloct06.pdf.
} 
mist paskelbta diagrama (žr. 1 pav.), kokią dalị valdžios atstovų „silovikai“ sudare nuo pat paskutiniojo SSRS prezidento Michailo Gorbačiovo laikų, per visą Jelcino valdymą ir galiausiai pirmuosius Putino valdymo metus iki 2003 metų.

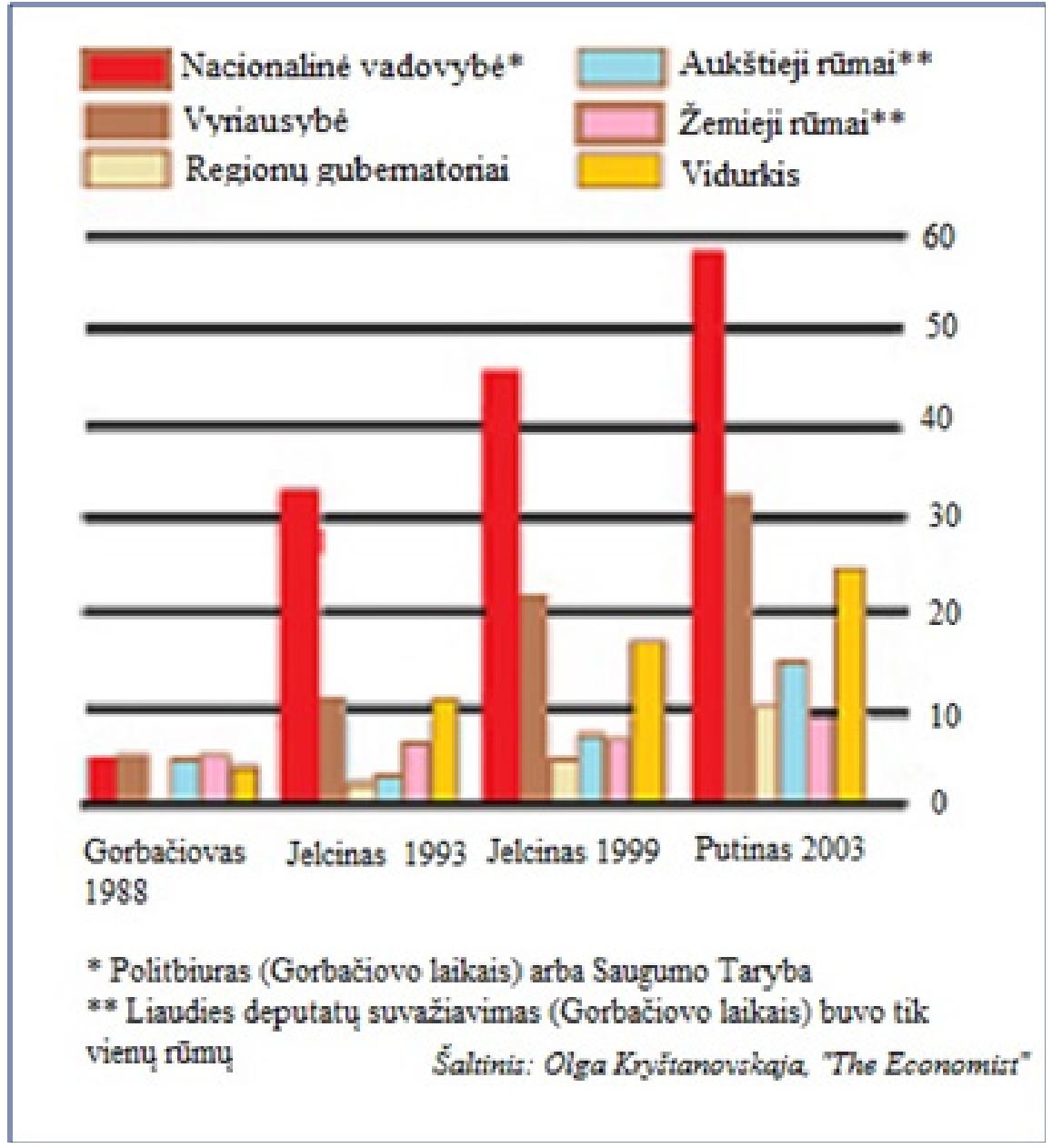

1 pav. „Siloviku““ isitvirtinimas Rusijos valdžioje

Žmonès iš karinių / saugumo struktūrų (\%) ịvairiose valdžios šakose

Ši diagrama akivaizdžiai atskleidžia, kad „silovikų“ issigalëjimas buvo itin nuoseklus ir proporcingas visą posovietinès Rusijos laikotarpị ir nèra susijęs vien tik su Putino atejjimu i valdžią. Tiesa, kad jau trečiaisiais Putino valdymo metais nacionalinèje Rusijos vadovybëje „silovikų“ buvo beveik 60 proc. Tačiau tiesa ir tai, kad paskutiniaisiais Jelcino valdymo metais Rusijos nacionalineje vadovybeje "silovikų“ jau buvo beveik 50 proc., o netgi Jelcino valdymo pradžioje 1993-aisiais jų buvo daugiau kaip 30 proc., kai Gorbačiovo valdymo 
laikais šis skaičius tebuvo vos keli procentai.

Todèl norint suprasti Rusijos režimo prigimtị reikia žvelgti gerokai giliau. „Putino iškilimas ị Rusijos prezidentus buvo ịvykių, kurie prasidejo mažiausiai ketvirčiu amžiaus anksčiau, kai Jurijus Andropovas, buvęs KGB vadovas, tapo Leonido Brežnevo ịpėdiniu Komunistų partijos generalinio sekretoriaus poste, rezultatas". Tai dar 2007 metais buvo pastebèta tikrai išsamioje žurnalo The Economist analizeje ${ }^{33}$.

Knygoje „FSB sprogdina Rusija“", kurią parašè vèliau Londone poloniu nunuodytas čia prieglobstị gavęs buvęs FST agentas Aleksandras Litvinenka ir 1978 metais ị JAV emigravęs istorikas Jurijus Felštinskis, taikliai pastebèta apie paties KGB išlikimą po SSRS žlugimo, kuris daug atskleidžia ir apie Putino režimo prigimti (kaip pastebejjo The Economist, šio režimo šaknų reikia ieškoti Andropovo valdymo laikotarpyje).

„Kelių transformacijų ir pavadinimų keitimų serijos, kurią inicijavo pati specialioji tarnyba, tikslas buvo nukreipti smūgi nuo valstybės saugumo tarnybos, kaip struktūros, išsaugoti ne tik pačią organizaciją, nors ir decentralizuotą, bet ir kadrus, archyvus, agentūrą. Milžinišką vaidmeni gelbèjant KGB nuo sutriuškinimo suvaidino Jevgenijus Savostjanovas Maskvoje ir Sergejus Stepašinas Leningrade. Ir vienas, ir kitas buvo demokratai ir buvo paskirti tam, kad reformuotų ir kontroliuotų KGB. Tačiau iš tikrųjų ir vienas, ir kitas iš pradžių buvo infiltruoti valstybés saugumo ị demokratinius judejjimus, o vèliau jau paskirti $\mathfrak{i}$ vadovaujamus postus naujojoje specialiojoje tarnyboje, kad neleistų demokratams sutriuškinti KGB. Ir nors daugybė kadrinių ir neetatinių KGB, MB (rus. Miniterstvo bezopasnosti - Saugumo ministerija), FSK, FSB (rus. Federalnaja služba bezopasnosti - Federalinè saugumo tarnyba) darbuotojų bėgant metams pasuko ị verslą arba politiką, struktūra iš esmès buvo išsaugota būtent Savostjanovo ir Stepašino dèka. Maža to, jei anksčiau KGB buvo politiškai kontroliuojama partijos, kuri tarnyboms buvo savotiškas stabdis, nes bet kuri rimta operacija buvo vykdoma tik su Politinio biuro pritarimu, tai po 1991 metų MB, FSK, FSB Rusijos erdvejje ėmè veikti visiškai savarankiškai ir nekontroliuojama“. Tokius faktus išdèstè Litvinenka ir Felštinskis jau minètoje knygoje $e^{34}$.

Prie to reiketų pridurti, kad vienu įtakingiausių žmonių Jelcino aplinkoje nuo pat jo atejimo ị valdžią Rusijoje laikytas Aleksandras Koržakovas buvo asmeninis Jurijaus Andropovo apsaugininkas. Absoliučios daugumos įtakingiausių Putino režimo atstovų šaknis galima rasti arba pačiame KGB,

\footnotetext{
${ }^{33}$ „The making of a neo-KGB state“, The Economist, Aug 23rd 2007, http://www.economist.com/ node/9682621.

34 Литвиненко А., Фельштинский Ю., ФСБ взрьвает Россию. Федеральная служба безопасности организатор террористических актов, похищений и убийств“, Eesti Päevaleht, 2007, http://www. felshtinsky.com/books/FSB/vtoroe_est/FSB.2nd.Rus.Estonia.pdf.
} 
arba struktūrose, kurios pagal Andropovo planą turejjo rengti kadrus Sovietų Sajungos reformavimui.

Buvusių KGB darbuotojų ir jiems artimų oligarchų pagrindu besikūrusios sistemos formavimąsi Jelcino valdymo metais ir paties Putino atẻjimą i valdžią jau minètas istorikas Felštinskis yra apibūdinęs taip: „Buvo kuriama struktūra, kuri turejo konkuruoti su Koržakovo vadovaujama prezidento apsaugos tarnyba, paralelinè FSB (SB-FSK) struktūrai. Po to Gusinskio, Bobkovo, Lužkovo ir Primakovo konkurentais tapo Putinas, Abramovičius, Berezovskis ir Vološinas. Laimejo antrieji. Galèjo laimèti pirmieji. Skirtumo nebūtų buvę jokio ${ }^{\text {“35. }}$.

Netiesiogiai tokius Felštinskio žodžius viename savo interviu yra patvirtinęs ir pats vienas iš Rusijos oligrachų Berezovskis, kurị daugelis laiko pagrindiniu žmogumi, atvedusiu ị valdžią Putiną.

2002 metais, kai jau nuo Putino režimo buvo priverstas slaptytis Londone, Berezovskis davè interviu garsiai Rusijos žurnalistei Julijai Latyninai. Kai Latynina paklausé, kodèl, jei Berezovskis jau toks stiprus, jis atsidūre emigracijoje Londone, o ne Kremliuje, oligarchas prisipažino: „Padariau vieną sisteminę klaidą - galvojau, kad pagrindinè jèga, kliudanti reformoms - tai komunistai. Bet tai - FSB, tiksliau, SSRS KGB“36.

Žurnalistei toks atsakymas nepasirode įtikimas. Ji èmè ginčytis, kad panašią idejją minètoje knygoje „FSB sprogdina Rusiją jau kèlè Felštinskis ir Litvinenka, bet Latyninai esą tai neatrodo rimta.

Štai, kaip skambejo Berezovskio atsakymas ị tokius Latyninos samprotavimus: „Ši organizacija išliko kaip dvasios brolystè, nusikaltimų brolystė. KGB buvo sovietų valstybės stuburas, ją sudaré žmonès, kuriuos mokė vykdyti nusikaltimus ir kuriems aiškino, kad tai ne nusikaltimai. Ir šie žmonès niekur nedingo. Taip KGB suskilo ị daugelị konkuruojančių grupuočių, veikiančių pagal savo arba svetimus interesus. Tačiau pasirodè, kad dezintegracija buvo paprasčiausia mimikrijos forma. Imkime, pavyzdžiui, Aleksandrą Koržakovą. Šis žmogus buvo asmeninis Andropovo apsaugininkas. Šị žmogų dešimt kartų kiaurai „peršvietė“. Ir jūs manote, kad jis savanoriškai pasiliko su atstatydintu Jelcinu. Aš stebèjau, kaip Jelciną bandė paversti alkoholiku, visišku nuliu. Jūs galvojate, kad tai irgi atsitiktinumas?"37

\footnotetext{
${ }^{35}$ Laurinavičius M., „Putin's Russia. Roots of today's regime date back to KGB under Andropov“, DELFI by The Lithuanian Tribune, December 24, 2014, http://en.delfi.lt/central-eastern-europe/putins-russia-rootsof-todays-regime-date-back-to-kgb-under-andropov.d?id=66748856; Laurinavičius M., „Putin’s Russia. The dangerous illusion of independent and western oligarchs", DELFI by The Lithuanian Tribune, June 19, 2015, http://en.delfi.lt/central-eastern-europe/putins-russia-the-dangerous-illusion-of-independent-andwestern-oligarchs.d?id=68286668.

${ }^{36}$ Латынина Ю. „С пистолетом Путина я зашел в кабинет Примакова“, Новая газета, № 35 , 20.05.2002, http://www.novayagazeta.ru/society/16756.html.

${ }^{37}$ Ten pat.
} 


\subsection{Atsitiktinumai virsta logiška grandine}

Yra daugybė viešos informacijos apie Andropovo sumanytą Sovietų Sąjungos reformų planą, šio plano igyvendinimui ruoštus kadrus, institucijas, kuriose tai buvo daroma, galų gale Sovietų Sąjungos turto išsidalijimą, dingusius KGB ir Komunistų partijos pinigus, jų plovimą Sovietų Sąungos žlugimo laikotarpiu, KGB įsitvirtinimą versle ${ }^{38}$.

Analizuojant visa tai sistemiškai tariami atsitiktinumai virsta logiška grandine. Juo labiau, jog tai, kad Andropovo sumanytas SSRS reformų planas iš tiesų egzistavo, kad su juo susiję ir vadinamieji jaunieji reformatoriai iš esmès parèmę valdžią Rusijoje po Sovietų Sajungos žlugimo, o planą rengè struktūros, kuriose jie dirbo, viešai, nors ir netiesiogiai, patvirtino dabartinès Putino vyriausybès narys ekonominès plètros ministras Aleksejus Uliukajevas ${ }^{39}$.

Kartą paklaustas, ar egzistavo asmeniškai Andropovo kuruotas SSRS ekonominès reformos projektas, kuriame dalyvavo visi vadinamieji jaunieji reformatoriai, Uliukajevas atsakè: „Žinoma, kad egzistavo! Tam dirbo svarbiausi mokslinių tyrimų institutai - pirmiausia, Visasąunginis taikomųjų sisteminių tyrimų institutas, Ekonomikos ir mokslo-technikos pažangos prognozavimo institutas ir panašūs. Tik mūsų „,kuratoriai“ nenumate kokybinių pasikeitimų“.

Akivaizdus faktas - po 1991 metų rugpjūčio pučo žlugimo būtent trys šiuose institutuose dirbę ekonomistai - Piotras Avenas, Jegoras Gaidaras ir Anatolijus Čiubaisas - staiga užèmė pačius aukščiausius postus Rusijos vyriausybëje. Reikšmingą liudijimą apie Gaidaro, Čiubaiso ir Aveno karjeras dabartinio Rusijos Dūmos deputato Aleksandro Chinšteino knygoje „Kaip žudo Rusiją ${ }^{40}$ pateikia Jelcino valdymo laikotarpiu vicepremjero pareigas Rusijos vyriausybeje ejjęs Michailas Poltoraninas. Beje, jis po SSRS žlugimo vadovavo specialiai komisijai, tyrusiai uždarus Politinio biuro archyvus ir turejjusiai juos išslaptinti. Pasak Poltoranino, visus tris (ir Gaidarą, ir Čiubaisą ir Aveną) visą laiką kontroliavo KGB. M. Poltoraninas esą archyvuose savo akimis matė tai patvirtinančius dokumentus.

Maža to, Poltoranino teigimu, tarp tų, kurie buvo ruošiami perimti valdžią žlungant SSRS, buvo ne tik Gaidaras, Čiubaisas ir Avenas, bet ir dabar antrą vietą turtingiausių rusų sąraše užimantis „Alfa group“ atstovas Michailas

\footnotetext{
${ }^{38}$ US House of Representatives, "Russian Money Laundering, Hearing before the Committee on Banking and Financial Services”, September 21, 22, 1999, Earley P. „Comrade J: The Untold Secrets of Russia's Master Spy in America After the End of the Cold War", Moscow's Gold: Soviet Financing of Global Subversion”, National Observer, No 40, 1999, http://www.nationalobserver.net/1999_autumn_campbell.htm; Albats Y. „KGB: State Within a State“, London, New York, I.B. Tauris Publishers, 1985.; Laurinavičius (supra note 36).

${ }^{39}$ Калашникова Н., „Восьмидесятники“, Itogi, №12 / 719 (22.03.10), http://www.itogi.ru/ nashe/2010/12/150106.html .

${ }^{40}$ Хинштейн А., Как убивают Россию, Москва: Олма Медиа Групп, 2007.
} 
Fridmanas, taip pat Berezovskis ir Putinui nepaklusę, todèl sunaikinti oligarchai Chodorkovskis ir Gusinskis.

Kaip toliau formavosi Putino režimas ir ypač kaip ir kodèl jo šaknys glūdi neskaidriose turto pasidalijimo po Sovietų Sąjungos žlugimo schemose išsamiai aprašyta Karen Dawishos knygoje „Putins Kleptocracy: Who Owns Russia“"

\section{Išvados}

Visa ši analizė pirmiausia atskleidžia, kad tradicinė Putino režimo kaip „valdžios vertikalès“ koncepcija prieštarauja realiai Rusijoje vykstantiems procesams arba bent jau yra itin sunkiai su jais suderinama.

Kita vertus, tokia analizė taip pat leidžia teigti, kad Putino režimas pradejjo kurtis gerokai anksčiau negu pats Putinas atėjo ị valdžią 2000 metais. Maža to, Putinas buvo tik vienas iš trijų realiausių kandidatų tapti Jelcino ipèdiniu ir tik palankiai susiklosčiusios aplinkybès ir jị rèmusių klanų pergalè prieš konkurentus lèmè, kad jis tapo Rusijos prezidentu.

Tačiau būtina pastebèti, kad kiti du iš minètų trijų realiausių kandidatų pakeisti Jelciną irgi buvo KGB atstovai - straipsnyje minètas Stepašinas, kuris, pasak Litvinenkos ir Feltišinskio, asmeniškai išgelbejjo KGB nuo sunaikinimo Sankt Peterburge, ir Jevgenijus Primakovas, kuris prisidejjo prie Andropovo plano reformuoti Sovietų Sąjungą ištakų.

Todèl galima teigti, jog net jeigu Putinas nebūtų tapęs prezidentu, iš tiesų Rusijoje nebūtų daug kas pasikeitę. Turint visa tai galvoje, visiškai kitaip skamba ir Putino žodžiai, ištarti kolegoms iš KGB ịpedinès Federalinės saugumo tarnybos (FSB), prieš pat jam oficialiai perimant Rusijos prezidento postą: „Grupé FSB darbuotojų, pasiųstų su priedanga dirbti Rusijos Federacijos vyriausybèje, sẻkmingai ịvykdè savo užduotị゙“.

Negalima teigti, kad Putino režimas yra tiesioginis Andropovo plano igyvendinimo rezultatas, nes Andropovą kažin ar būtų galima įtarti norejjus SSRS žlugimo, o pats Putinas ši žlugimą yra pavadinęs didžiausia XX amžiaus geopolitine katastrofa.

Tačiau galima pagrịstai teigti, kad KGB, nors, pasak Berezovskio, ir „suskilo i̇ daugelị konkuruojančių grupuočių, veikiančių pagal savo arba svetimus interesus" nuosekliai ir planingai siekè sugrịžimo ị valdžią nuo pat Sovietų Sąjungos žlugimo.

Todèl tiek pati dabartinè klaninė KGB pagrindu susikūrusi Putino reži-

\footnotetext{
${ }^{41}$ Karen Dawisha, Putin's Kleptocracy: Who Owns Russia, Simon \& Schuster, 2014.
} 
mo sistema, tiek ir Rusijos tyrinèjimas būtent šiuo aspektu verčia daryti išvadą, kad tarp daugelio Rusijos analitikų, visuomenès veikèjų ir net politikų senokai įsitvirtinęs terminas „kolektyvinis Putinas“ dabartinę Rusijos valdžios sistemą apibūdina daug tiksliau negu valdžios vertikalè.

Tai iš esmès reiškia, kad paties Putino vaidmuo (nors jis tikrai nèra nesvarbus) dažniausiai per daug sureikšminamas, o pačios sistemos, kuri, beje, ir atvede i valdžią Putiną, - per daug sumenkinamas. Sprendimai šalyje tikrai nèra vienasmeniai, o Putinas iš tiesų yra tik šios valdžios sistemos simbolis, nors, žinoma, tikrai nepraradęs to teisèjo ar tarpininko vaidmens.

Šis „kolektyvinis Putinas“ lemia sprendimus, kurie dažnai tikrai nèra vienareikšmiai ir atitinkantys „valdžios vertikalès“ koncepciją, ne tik Rusijos viduje, bet ir jos užsienio politikoje.

„Kolektyvinis Putinas" turi Sovietų Sąjungos KGB mentalitą, todèl pagrindinis šio režimo tikslas visuomet buvo ir toliau bus ne tik sugrąžinti Rusijai globalinès galios statusą, tačiau ir ịveikti Vakarus, pirmiausia JAV. Todèl agresyvi jo politika neturètų stebinti. Tačiau priemonès ir taktika, už kuriuos pasisako skirtingi režimo sparnai, gali smarkiai skirtis.

Šio režimo pagrindas yra korupcija ir nusikalstama veikla, nes būtent šiuo pagrindu jis susikūrè. Todèl tikètis, kad pats režimas judès bent jau vakarietiškų verslo standartų ir teisinès valstybės link, būtų naivu.

Tačiau svarbiausia yra tai, kad visa ši analizè rodo, neverta tikètis, kad šis režimas galètų kaip nors iš esmès keistis net ir Putinui dèl vienos ar kitos priežasties palikus postą.

Vašingtonas, 2015 metu spalis-lapkritis 